\section{'Pink Rosa' Strawberry}

Agnieszka Masny ${ }^{1}$ and Edward $\dot{Z}$ urawicz

Department of Breeding of Horticultural Crops, Research Institute of

Horticulture, Konstytucji 3 Maja 1/3, 96-100 Skierniewice, Poland

Additional index words. Fragaria $\times$ ananassa, cultivar, small fruits, fruit breeding, health benefits

'Pink Rosa' is a new late strawberry cultivar from the Research Institute of Horticulture in Skierniewice, Poland broadening the assortment of strawberry cultivars for fresh market. The fruit of 'Pink Rosa' are large, regular in shape (wide conical) with an attractive orange-pink skin color. The plants are tolerant to freezing injuries and have low susceptibility to leaf fungal diseases such as strawberry leaf spot (caused by Mycosphaerella fragariae), leaf scorch (caused by Diplocarpon earliana), and powdery mildew (caused by Podosphaera aphanis) and soilborne disease such as verticillium wilt (caused by Verticillium dahliae). 'Pink Rosa' is also recommended for off-season (delayed) production in the open field and under high tunnels.

\section{Origin}

'Pink Rosa' was selected in 2005 at the Fruit Breeding Department of the Research Institute of Horticulture (formerly Research Institute of Pomology and Floriculture), Skierniewice, Poland among seedlings received from the progeny of a cross between 'Granda' and 'Sophie' (Fig. 1) made in 2004. The cross was made under the direction of A. Masny and E. Żurawicz. Both parents differ widely in terms of their pedigree, geographical origin, and many other agronomic features. The female parent 'Granda' is a short-day type, late cultivar, obtained in Italy (Cesena, Po Valley) from the cross of Sel. 83.5.8 (78.65.1 $\times$ 'Etna') $\times$ 'Marmola$\mathrm{da}^{\circledR}$ Onebor' made in 1989. It was selected in 1991 and introduced in commercial production in Italy in 1999 (Faedi et al., 2009). 'Granda' produces large and regular-shaped conical fruit. The skin is orange red, homogenous in color, and very glossy. The flesh is bright red, firm, and very tasty. 'Granda' is tolerant to soil-borne pathogens and resistant to Colletotrichum acutatum, but susceptible to Alternaria alternata and Xanthomonas

Received for publication 22 July 2015. Accepted for publication 26 Aug. 2015.

This work was co-financed through a grant from the European Regional Development Fund of the European Union under the Innovative Economy Operational Program (contract no. UDA-POIG.01.03.02-00-033/ $12-00)$.

We thank J. Markowski and his team for performing chemical analyses of the fruit.

${ }^{1}$ Corresponding author. E-mail: agnieszka.masny@ inhort.pl. fragariae (Finn, 2000). Other advantages of 'Granda' in Polish agro-climatic conditions include high productivity and good winterhardiness (Żurawicz et al., 2004). 'Sophie', the male parent of 'Pink Rosa', is a very late, short-day cultivar selected in 1988 at Horticultural Research International, East Malling, UK, by D.W. Simpson. 'Sophie' originated from the cross ('Hapil' $\times$ 'Streamliner') $\times$ 'Kent' made in 1987 . This cultivar was introduced in commercial cultivation in UK in 1997 (Finn, 2000). The fruit of 'Sophie' have very regular, conical shape, and medium large size (Faedi et al., 2009) with dark red and slightly glossy skin, similar to 'Honeoye' (Finn, 2000). The fruit flesh is red, moderately firm, and slightly acid in flavor (Finn, 2000). Plants of 'Sophie' are very vigorous with sparse habit. However, in trials conducted in Poland they were susceptible to powdery mildew and verticillium wilt (Masny and Żurawicz, 2005). During the evaluation 'Pink Rosa' was tested as the selected breeding number T-04052-06.

\section{Description}

Performance. Field trials using newly selected clones, including 'Pink Rosa', were performed in the Pomological Orchard of the Research Institute of Horticulture, Skierniewice, Central Poland (lat. 51.959 $\mathrm{N}$, long. $20.139^{\circ} \mathrm{E}$ ), from 2008 to 2011 . The standard cultivars used in the present experiment were 'Honeoye' and 'Elsanta', both commonly grown in Poland. The experiment was established in the Spring 2008 in a random block design, with four replicates. Each replicates consisted of 15 plants cultivated in single row spaced at $0.25 \times 1.0 \mathrm{~m}$. In $2009-11$, the plant was assessed for its growth habit and productivity, external and internal fruit quality, and plant susceptibility to strawberry leaf spot, leaf scorch, powdery mildew, and verticillium wilt. The fruit were harvested twice weekly and sorted into two categories: marketable ( $\geq 1.8 \mathrm{~cm}$ in diameter) and unmarketable ( $<1.8 \mathrm{~cm}$ in diameter or misshapen). The fruit ripening time was expressed as the Faedi index, indicating the number of days from 1 Jan. to harvesting 50\% marketable yield (Faedi et al., 1988). The average fruit weight was calculated as the ratio of the yield and the number of healthy fruits collected. Fruit firmness was determined using the INSTRON 5542 penetrometer (Instron Corporation, Canton, MA) based on 3 samples of 20 marketable fruits collected during the third, fourth, and fifth harvest. The internal fruit quality (soluble solids, ascorbic acid, and anthocyanin content) was assessed based on samples of 20 fruits randomly collected during the third, fourth, and fifth harvest and frozen at $-25^{\circ} \mathrm{C}$ until further processing. Before fruit quality being assessed, fruits were disintegrated in solid $\mathrm{CO}_{2}$ at $-78.5{ }^{\circ} \mathrm{C}$ with Blixer 3 (Robot Coupe, France). Soluble solids were determined using refractometer RE 50 (Mettler Toledo, Japan). To measure the ascorbic acid by high-performance liquid chromatography (HPLC), samples were additionally disintegrated in liquid $\mathrm{N}_{2}$ at $-195.8^{\circ} \mathrm{C}$ using A11 Basic (IKA-Werke, Germany) mill and extracted with $6 \%$ metaphosphoric acid at 1 to $4{ }^{\circ} \mathrm{C}$. After 2-min homogenization with Ultra Turrax T35 Basic T25 (IKAWerke), the samples were transferred into a volumetric flask, filled up with metaphosphoric acid and filtered. After dilution and repeated filtration, the content of ascorbic acid was determined using HPLC method with chromatograph Agilent HP 1100 (Waldbronn, Germany) with DAD detector at $244 \mathrm{~nm}$; two interlinked columns Supelco LC-18 $(250 \times 4 \mathrm{~mm}) ; 30{ }^{\circ} \mathrm{C}$; mobile phase $-1 \%$ phosphoric buffer $(\mathrm{pH}=2.5)$, flow rate$0.8 \mathrm{~mL} \cdot \mathrm{min}^{-1}$. The quantification of anthocyanins in frozen strawberries was made by the $\mathrm{pH}$ differential method (Giusti and Wrolstad, 2001; Wrolstad, 1976). Anthocyanins extracts were prepared by homogenization of disintegrated in solid $\mathrm{CO}_{2}$ fruits (Blixer 3 disintegrator; France) in acidified methanol.

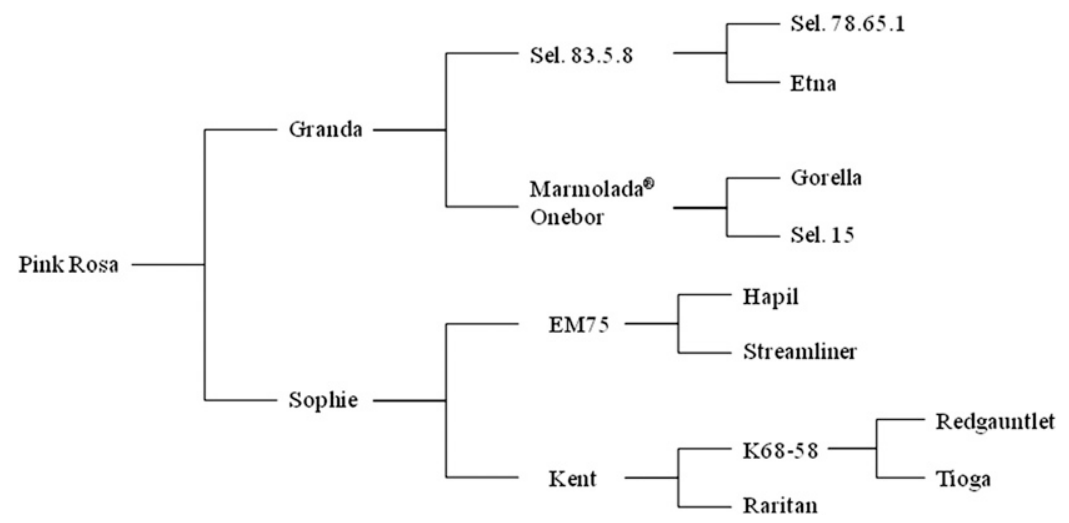

Fig. 1. Pedigree of 'Pink Rosa' strawberry. The female parent is listed on the upper side of each bifurcation. 
After homogenization (Ultra Turrax T25 Basics IKA Werke), an extract was centrifuged $1500 g_{n}$ for $10 \mathrm{~min}$ (Sigma 3K30; Germany) and supernatant was diluted appropriately. Extinction of strawberries extracts in potassium chloride buffer $(\mathrm{pH}=$ $1.0)$ and sodium acetate buffer $(\mathrm{pH}=4.5)$ were measured simultaneously at 498 and $700 \mathrm{~nm}$ after $60 \mathrm{~min}$ of incubation at ambient temperature in the dark using Cary $300 \mathrm{E}$ spectrophotometer (Varian, Australia). Then the difference of absorbance was calculated. The content of total anthocyanins was expressed as pelargonidin-3-glucoside (mg per100 $\mathrm{g}$ of fruits). A molar absorptivity of 22,400 was used (molecular weight of $433.2 \mathrm{~g} \cdot \mathrm{mol}^{-1}$ ).

Plant susceptibility to strawberry leaf spot, leaf scorch, powdery mildew, and verticillium wilt was evaluated using a $0-4$ ranking scale, where 0 means no visible symptoms of disease and 4 means plant dying as a result of heavy pathogen infection.

Flowering and fruit. In Central Poland, the bloom period of 'Pink Rosa' is late (end of May). The flowers are numerous, large, and hermaphroditic, with a calyx diameter much smaller than that of the corolla. The corolla has six to eight overlapping white petals. The inflorescences are produced on medium long and moderately erect peduncles, and the flowers develop beneath the leaf canopy. The fruit of 'Pink Rosa' are attractive-very regular, wide conical, or cordiform (Fig. 2), and significantly larger (14.2 g, Table 1) than fruit of 'Elsanta' and 'Honeoye'. The skin color of 'Pink Rosa' is pink orange to pink red (close to the number 1 of the CTIFL strawberry color code), uniform, and moderately glossy. Yellow achenes are inserted below the fruit surface level. The fruit flesh is a uniform orange-red color, and significantly firmer than that of 'Elsanta' and 'Honeoye' (Table 1), but having small internal cavity (Fig. 3). The calyx is firmly attached, and sunken into the fruit. The calyx diameter is $\approx 25 \%$ to $30 \%$ smaller than that of the fruit (Fig. 3). The narrow sepals are slightly raised upward. The fruit is tasty, slightly acidic, and moderately aromatic. In our studies conducted in 2009-11, fruit of 'Pink Rosa' contained, on average, $8.27 \%$ ${ }^{\circ}$ Brix of the soluble solids and $27.5 \mathrm{mg} / 100 \mathrm{~g}$ of fresh fruit of anthocyanins, similar to fruit

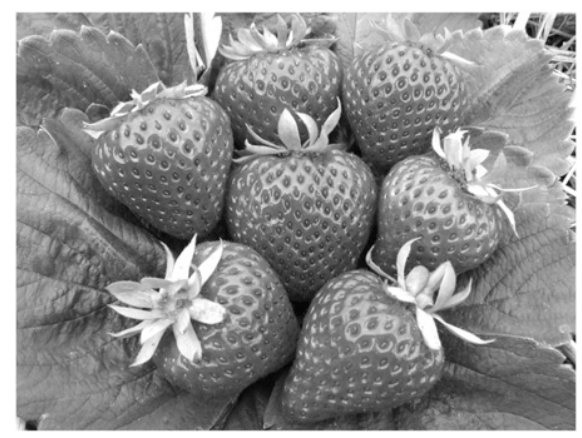

Fig. 2. 'Pink Rosa' fruit. of 'Elsanta' and 'Honeoye' (Table 2). Fruit of 'Pink Rosa' were significantly lower in ascorbic acid than that of 'Elsanta' (57.0 mg/100 g; Table 2). Our additional analyses, performed in 2012-13 in frame of the EUBerry project (seventh Frame Program) showed, that the fruit of 'Pink Rosa' contained $317 \mathrm{mg} / 100 \mathrm{~g}$ of total phenols and $16.2 \mathrm{mg} / 100 \mathrm{~g}$ of ellagic acid on average (EUBerry, 2013).

Shelf life of the fruit of 'Pink Rosa' is also very good. No changes in fruit glossiness and color and only a slight drooping of calyx was observed after keeping the mature fruit in the room temperature $\left(\approx 22{ }^{\circ} \mathrm{C}\right)$ during $48 \mathrm{~h}$, as compared with the fresh fruit; with no bruising or fruit rot was noted by that time (Table 3).

Ripening and harvest. In Central Poland, fruit ripening of 'Pink Rosa' starts in midJune (on average) and ends by mid-July. The Faedi index for this cultivar is 173 on average, which is $7-8 \mathrm{~d}$ later than compared with 'Honeoye' and 'Elsanta' (Table 1). Thus, 'Pink Rosa' is considered a lateripening cultivar. In field trials under Polish agro-climatic conditions, 'Pink Rosa' is as productive as 'Elsanta' (Table 1). However,

Table 1. Fruit ripening time, productivity, fruit weight, and fruit firmness of 'Pink Rosa' grown in a field trial at Skierniewice, Poland (average for 2009-11).

\begin{tabular}{lcccc}
\hline Cultivar & $\begin{array}{c}\text { Fruit ripening time } \\
(\text { Faedi index })^{\mathrm{z}}\end{array}$ & $\begin{array}{c}\text { Marketable yield } \\
(\mathrm{g} / \mathrm{plant})\end{array}$ & Fruit wt $(\mathrm{g})$ & Fruit firmness $(\mathrm{N})$ \\
\hline Honeoye & $165.1 \mathrm{a}^{\mathrm{y}}$ & $930.5 \mathrm{~b}$ & $10.5 \mathrm{a}$ & $1.84 \mathrm{a}$ \\
Elsanta & $165.8 \mathrm{a}$ & $533.8 \mathrm{a}$ & $11.0 \mathrm{a}$ & $1.81 \mathrm{a}$ \\
Pink Rosa & $172.9 \mathrm{~b}$ & $616.1 \mathrm{a}$ & $14.2 \mathrm{~b}$ & $2.63 \mathrm{~b}$ \\
\hline
\end{tabular}

${ }^{\mathrm{z}}$ The Faedi index indicates the number of days from 1 Jan. to harvesting $50 \%$ of marketable yield.

${ }^{y}$ The means within columns followed by the same letter are not significantly different at $P>0.05$ (Duncan's $t$ test).

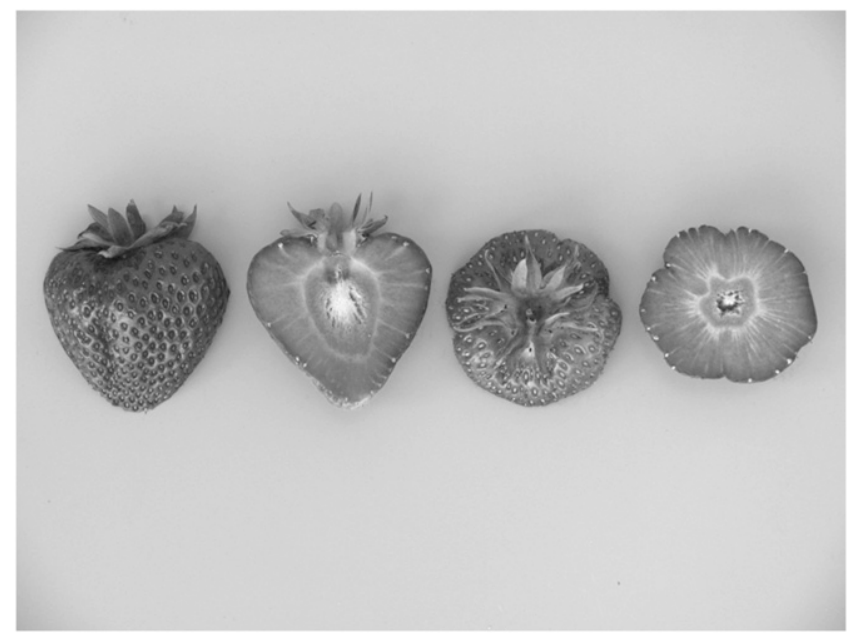

Fig. 3. Flesh appearance of 'Pink Rosa' fruit.

Table 2. Fruit composition of 'Pink Rosa' grown in a field trial at Skierniewice, Poland (average for 2009-11).

\begin{tabular}{lccc}
\hline Cultivar & Soluble solids $(\%)$ & $\begin{array}{c}\text { Ascorbic acid } \\
(\mathrm{mg} / 100 \mathrm{~g})\end{array}$ & $\begin{array}{c}\text { Anthocyanins } \\
(\mathrm{mg} / 100 \mathrm{~g})\end{array}$ \\
\hline Honeoye & $8.14 \mathrm{a}^{\mathrm{z}}$ & $55.0 \mathrm{a}$ & $32.9 \mathrm{a}$ \\
Elsanta & $8.65 \mathrm{a}$ & $71.3 \mathrm{~b}$ & $32.8 \mathrm{a}$ \\
Pink Rosa & $8.27 \mathrm{a}$ & $57.0 \mathrm{a}$ & $27.5 \mathrm{a}$ \\
\hline
\end{tabular}

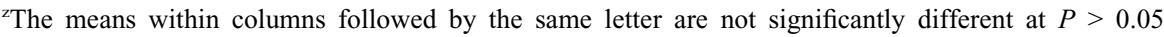
(Duncan's $t$ test).

Table 3. External fruit quality of 'Pink Rosa' after $48 \mathrm{~h}$ in the room temperature $\left(\approx 22{ }^{\circ} \mathrm{C}\right.$; Skierniewice, 2014).

\begin{tabular}{lccccc}
\hline Cultivar & Skin color & $\begin{array}{c}\text { Skin } \\
\text { glossiness }\end{array}$ & Bruising $^{\mathrm{y}}$ & $\begin{array}{c}\text { Calyx } \\
\text { freshness }\end{array}$ & ${\text { Fruit } \text { rot }^{\mathrm{v}}}^{\mathrm{y}}$ \\
\hline Honeoye & 1 & 2 & 1 & 2 & 3 \\
Elsanta & 4 & 4 & 4 & 5 & 5 \\
Pink Rosa & 5 & 5 & 5 & 4 & 5 \\
\hline
\end{tabular}

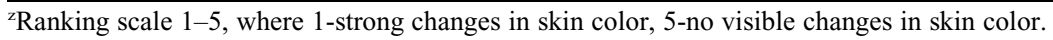

${ }^{y}$ Ranking scale 1-5, where 1-strong decrease of skin glossiness, 5-no visible changes in skin glossiness. ${ }^{x}$ Ranking scale $1-5$, where 1 -strong bruising, 5-no visible bruising.

${ }^{\text {w}}$ Ranking scale 1-5, where 1-strong decrease of calyx freshness, 5-no visible changes in calyx freshness. vanking scale 1-5, where 1-strong fruit rot, 5-no fruit rot. 
our studies conducted in 2012 and 2013 showed that in soilless production under plastic canopies and in high tunnels for season extension the marketable yield of 'Pink Rosa' was significantly higher than that of 'Elsanta' (Masny and Zurawicz, 2015).

Plant description. Plants of 'Pink Rosa' are more vigorous than those of 'Elsanta', with a semiupright growth habit and sparse leaf canopy (Fig. 4). The leaves are long and have large blades. The terminal leaflet is concave along a midvein, much longer than wide, with acute shape of base and serrate to crenate margins. The upper surface of the leaflets is light green and medium glossy. The petioles have medium numerous, horizontal hairs. Plants of 'Pink Rosa' grow freely, producing a moderate number of daughter

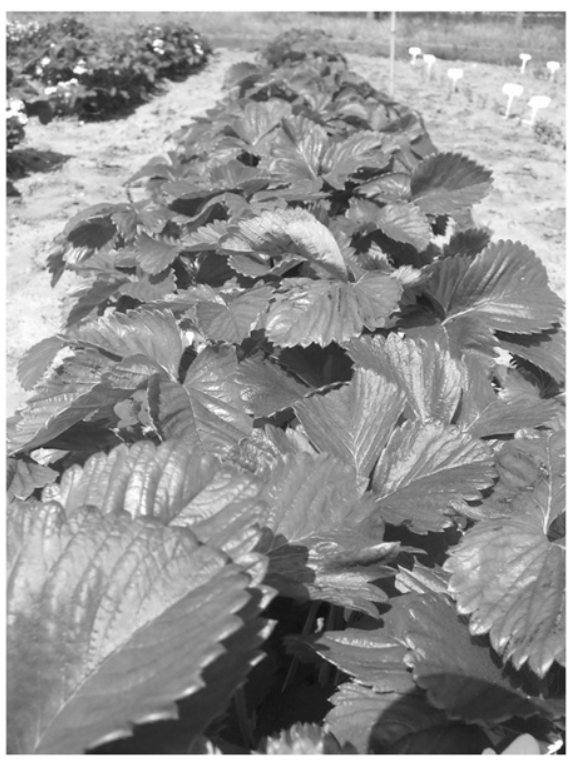

Fig. 4. 'Pink Rosa' plant habit.

Table 4. 'Pink Rosa' plant susceptibility to fungal diseases in a field trial at Skierniewice, Poland (average for 2009-10).

\begin{tabular}{lcccc}
\hline Cultivar & Strawberry leaf spot $^{\mathrm{z}}$ & Leaf scorch & Powdery mildew $^{\mathrm{z}}$ & Verticillium wilt $^{\mathrm{z}}$ \\
Honeoye & $0.0 \mathrm{a}^{\mathrm{y}}$ & $1.3 \mathrm{ab}$ & $0.7 \mathrm{~b}$ & $1.9 \mathrm{c}$ \\
Elsanta & $0.0 \mathrm{a}$ & $0.8 \mathrm{a}$ & $1.4 \mathrm{c}$ & $1.0 \mathrm{~b}$ \\
Pink Rosa & $0.1 \mathrm{a}$ & $1.4 \mathrm{~b}$ & $0.1 \mathrm{a}$ & $0.1 \mathrm{a}$
\end{tabular}

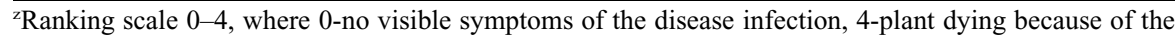
disease infection.

'The means within columns followed by the same letter are not significantly different at $P>0.05$ (Duncan's $t$ test). plants. The runners are sparsely pubescent with moderate anthocyanins coloration. Every year, the plants produce a few new crowns, on which flowers for the next season are formed.

Frost and disease susceptibility. In Polish climatic conditions, plants of 'Pink Rosa' overwinter better than plants of 'Elsanta'. Significant freezing injuries of 'Pink Rosa' (resulting in weaker plant growth vigor and lower productivity) were observed only after winters when the temperatures were very low (below $-20{ }^{\circ} \mathrm{C}$ ) and snow cover was thin. Artificial freezing tests with potted frigo plants, conducted at freezing chamber (BINDER GmbH, Germany) at the temperature of $-12{ }^{\circ} \mathrm{C}$ for $3 \mathrm{~h}$ also showed much higher resistance of 'Pink Rosa' in comparison with 'Elsanta' plants (Masny and Żurawicz, 2013). During several years of assessment, no flower buds, flowers, and fruit sets were damaged by late spring frosts due to late flowering time. Based on multiyear field observations, we found that 'Pink Rosa' plants are highly resistant to fungal leaf diseases such as strawberry leaf spot and powdery mildew as well as soil-borne verticillium wilt (Table 4). However, slight symptoms of leaf scorch were observed in some seasons.

'Pink Rosa' is of high value as a late cultivar providing firm and attractive fruits. Moreover, in regions of temperate climate 'Pink Rosa' does not need such intensive plant protection against powdery mildew as 'Elsanta', shows better winterhardiness and good tolerance to verticillium wilt.

\section{Availability}

'Pink Rosa' has been submitted to the Polish Register of Fruit Plant Varieties conducted by the Polish Research Center for Cultivar Testing (in Polish Centralny
Ośrodek Badania Odmian Roślin Uprawnych). In Europe, 'Pink Rosa' is submitted for protection by EU Plant Variety Rights (Application Number 20131696). Certified 'Pink Rosa' plants are being currently in propagation with the licensed nurseries in Poland.

\section{Literature Cited}

EUBerry. 2013. Strawberry database germplasm. Deliverable d 1.1. 14 July 2015. <http://www. euberry.univpm.it/sites/www.euberry.univpm. it/files/euberry/documenti/D1.1\%20Data\%20base/ Revisione/Summary-Genotype\%20characteristics \%20-\%20WP1\%207_2_14\%20last\%20versionStrawberry.pdf/>.

Faedi, W., G. Baruzzi, P. Lucchi, and P. Sbrighi. 2009. Monografia di cultivar di Fragola (Strawberry Cultivar Monography). VII Convegno Nazionale "La Fragola: Presente e Futuro", Marsala, Italy, 25-30 Mar. 2009. Regione Siciliana Assessorato Agricoltura e Foreste, Roma, Italy.

Faedi, W., P. Rosati, and N. D'Ercole. 1988. The strawberry breeding program for North Italy. Acta Hort. 265:53-68.

Finn, C.E. 2000. Strawberry. In: W.R. Okie (ed.). Register of new fruit and nut varieties - list 40. HortScience 35:821-824.

Giusti, M.M. and R.E. Wrolstad. 2001. Characterization and measurement of anthocyanins by UV-visible spectroscopy, p. F1.2.1-F1.2.13. In: R.E. Wrolstad (ed.). Current protocols in food analytical chemistry. Wiley, New York, NY.

Masny, A. and E. Żurawicz. 2005. Ocena wartości fenotypowej wybranych genotypów truskawki w kolekcji odmian Instytutu Sadownictwa i Kwiaciarstwa w Skierniewicach. Zeszyty Naukowe ISK 13:75-81.

Masny, A. and E. Żurawicz. 2013. Susceptibility of Selected Strawberry Cultivars to Low Temperatures in Natural and Controlled Conditions, $\mathrm{p}$. 70-73. In: M. Pukacki and S. Pukacka (eds.). Proc. $18^{\text {th }}$ Cold Hardiness Seminar in Poland, Kórnik, 14-15 May 2013. Poligrafia Marketing Finanse, E. Stachowiak, Wagrowiec, Poland.

Masny, A. and E. Żurawicz. 2015. Season extension possibilities in two Polish June-bearing strawberry cultivars. Acta Sci. Pol. Hortorum Cultus 14:115-127.

Wrolstad, R. 1976. Colour and pigment analyses in fruit products. Agricultural Expt. Sta., Oregon State Univ., Corvallis, Sta. Bul. 624:1-17.

Żurawicz, E., D. Kruczyńska, A. Masny, and K. Pierzga. 2004. Field performance of selected domestic and foreign strawberry cultivars grown at two sites of Poland. Acta Hort. 663:919-922. 